\title{
TECNOCIÊNCIA E COMPLEXIDADE DA VIDA
}

EDGARD DE ASSIS CARVALHO

Professor do Departamento de Antropologia, Coordenador do Núcleo de Estudos da Complexidade da PUC-SP

\begin{abstract}
Resumo: O princípio responsabilidade abre a possibilidade de uma ética planetária fundada no religamento, na compreensão, na magnanimidade e na resistência. Mediante estas práticas, fundadas na inseparabilidade da cultura científica e da cultura das humanidades, coloca-se a possibilidade da restauração sustentável de Gaia, mesmo que cenários do futuro encontrem-se ainda atrelados ao desenvolvimento unidimensional da biotecnologia, da robótica e da neurotecnologia.

Palavras-chave: ética e ciência; mudança tecnológica.
\end{abstract}

$\mathrm{A}$ cisão entre a cultura científica e a das humanidades permanece intocada até os dias de hoje. Produto da visão cartesiana e newtoniana que se constituiu em paradigma do mundo ocidental, essas duas culturas não se intercomunicam, cada uma vivendo às custas dos escombros da outra. Malgrado os esforços de múltiplas áreas do conhecimento em rejuntar saberes e repensar o objeto complexo, essas iniciativas são dissipações, brechas que não conseguem abalar o sólido edifício das dualidades instaladas e consolidadas no universo da política, da economia e da própria ciência. Em 1959, Charles Snow soube melhor do que ninguém avaliar os efeitos deletérios dessa incomunicabilidade, ao afirmar que "quando esses dois sentidos se desenvolvem separados, nenhuma sociedade é capaz de pensar com sabedoria" (Snow, 1995:72).

A existência de uma terceira cultura formada pelas ciências da sociedade, que se incumbisse de manter boas relações tanto com cientistas quanto com literatos, deixouse contaminar pelo estigma da separação. Com isso, o panteon do conhecimento redividiu-se de novo, constituído agora pelas ciências da natureza, pelas ciências da cultura e pelo imaginário presente nas artes, na literatura e na poesia. Incomunicáveis, essas três galáxias foram contaminadas pelo desenvolvimento fantástico da tecnociência, que selou de vez as mais variadas formas de dominação do homem sobre a natureza, impedindo que itinerários ra- cional-lógico-dedutivos e mítico-imaginários se retroalimentassem mutuamente.

A insistência de Snow de que era preciso agir rápido e repensar a educação em moldes menos especializados e fragmentados, e isso do ensino fundamental à universidade, não encontrou eco em planejadores e gestores, que se incumbiram de implantar o divórcio entre tecnologia e humanismo, entre razão e desrazão. É bem verdade que o termo cultura tem múltiplas acepções, que vão desde refinamento e sofisticação, até soberba e erudição. Se o conceito tivesse deixado de lado essas acepções e passasse a ser identificado simplesmente com a práxis cognitiva planetária gerada por grupos sociais múltiplos, a distinção entre cultura científica e humanista certamente cairia por terra. É claro que quando olhamos de frente para esse planeta globalizado, que inclui e exclui por uma dialética perversa e fóbica, batemos de frente na velocidade unidimensional e irreversível do progresso, instalada a partir da revolução mercantil do século 16 , consolidada com a revolução industrial do século 18 e solidificada com a revolução digital do 20 .

Opondo definitivamente magia e ciência, a idéia de progresso ganhou força, passando a reprimir qualquer tipo de cognição que não fosse regida pela causalidade e pelo determinismo e não aspirasse atingir verdades paradigmáticas consensuais. O chamado paradoxo neolítico chega a parecer inocente quando se depara com a voracidade 
que o controle da natureza apresentou nos tempos modernos. Mesmo que se assuma cognitiva e politicamente com Claude Lévi-Strauss (1962) a inexistência de diferença de natureza e grau entre os pensamentos mágico e científico, a hipermodernidade preferiu concentrar-se apenas no prometeísmo da ciência e da razão.

A noção de progresso parece andar em crise e, como apontou Paolo Rossi, temas como a escravidão do homem, a erosão da subjetividade, as extinções de espécies vegetais e animais retornaram à cena político-cultural de modo obsessivo, sinalizando a urgência de uma tomada de posição diante dessa geopolítica do caos. Ao que tudo indica, "o que é moderno não coincide mais com o que é humano" (Rossi, 2000:97). Esse antagonismo entre modernidade e humanidade fez com que a condição humana passasse a contar pouco diante da hegemonia da regulação das instituições, do narcisismo da política e da arrogância da ciência. Por isso, "olhar para o futuro assemelha-se a uma viagem oceânica em frágeis caravelas" (Rossi, 2000:130).

No contexto dessa viagem sem destino, a devastação das águas, ares e terras espelha, de modo substantivo, a fragilidade dessas caravelas imaginárias, cujos condutores são aqueles que ainda acreditam nas forças de conjunção que solidarizam, fraternizam e universalizam. Mesmo diante de mares bravios e da pirataria escondida em potentes submarinos, essa consciência telúrica ampliouse consideravelmente a partir dos anos 70 , consubstanciando-se em inúmeros encontros transnacionais que, sem diabolizarem a noção de desenvolvimento, passaram a postular que ele deveria ser norteado pela sustentabilidade. "O desenvolvimento é durável se as gerações futuras herdam um meio ambiente cuja qualidade seja pelo menos igual ao das gerações precedentes" (Ramonet, 1998:7).

O ponto de partida de qualquer iniciativa regida pela sustentabilidade requer uma crítica contundente à civilização tecnológica, impelindo indivíduos e sociedades a se mobilizarem contra a violentação da vida e a desolação da terra. O planeta sinaliza um certo cansaço diante de vacas loucas, águas contaminadas, dejetos tóxicos, catástrofes nucleares, andróides gênicos, máquinas espirituais e próteses corpóreas siliconadas. Ao que tudo indica, a mutação contemporânea, regida por uma taxa ampliada de acumulação material e imaterial que encanta os "donos do poder", vem gerando um desencantamento recalcado, cujos sintomas são visíveis a olhares mais complexos e sensíveis.
Essas potencialidades pervertidas das tecnologias ganham expressão máxima no sistema desigual de trocas que atravessa o planeta em sua totalidade. Ao analisá-las, René Passet (1998:65) afirmou que "os fluxos transfronteiriços de mercadorias representam, em sua maioria, trocas inter ou intra-firmas transnacionais". Com isso, os EstadosNações não conseguem mais controlar a massa das mercadorias e isso porque "os capitais circulam mais fácil e rapidamente do que as mercadorias" (Passet, 1998:65), como se estivessem submetidos a estrutura virtual invariante, situada além e aquém dos homens.

Essa "nova ordem mundial" inundou de desigualdades todas as sociedades sem distinção de longitude ou latitude, aumentando os sem-emprego, os sem-terra, os sem-teto. Todas estas ausências sociais, por vezes circundadas por uma vitimização e infantilização excessivas, repercutem a cada dia na pauperização do trabalho e da vida. Se deixadas a seu bel-prazer, conterão três possibilidades: ou o sistema se autodestrói, ou se recompõe por soluções paliativas, ou se nega por uma utópica revolta civil acionada pela legião dos estarrecidos do planeta. Na verdade, não há como identificar nesse espaço/ tempo geopolítico aonde se localizam os novos inimigos do mundo, pois eles se encontram disseminados, como um monstro de múltiplas cabeças, entre os setores constitutivos das classes dominantes que detêm o controle do poderio nuclear, do narcotráfico, do crime organizado, da desfaçatez midiática e dos cinismos da representação política.

A world culture, expressão crítica utilizada por Ramonet (1998), que deslocalizou unidades de produção e aglutinou unidades de consumo conspícuo, gerou um espaço econômico transnacional e transpolítico capitaneado pelos EUA, Japão, União Européia, mesmo que terrorismos, neonazismos, corrupções e até traições conjugais empanem o brilho que o bloco pretende exibir, nem sempre com sucesso. Para que a reprodução dessa máquina mortífera se amplie sem traumatismos, a comunicação e o mercado passaram a ser os dois paradigmas estruturantes do pensamento, incumbidos de aplacar os dissidentes e incensar os prosélitos.

Essa pacificação e passividade tramadas nos gabinetes do poder instituído vêm esbarrando em alguns problemas, e isso porque a ampliação da insignificância do mundo começa a exigir reflexões éticas sobre a ciência e a técnica. Em primeiro lugar, cabe pensar um pouco sobre o significado dessa palavra. Quem se incumbiu dessa tarefa, de modo irretocável, foi Cornelius Castoriadis (1996). Não 
se trata, apenas, de uma insignificância na cultura ou na política, mas também no pensamento e nos pensadores acometidos pelo conformismo e pela apatia, incapazes de enxergarem para além dos contornos do infinitamente pequeno, especialistas nos fragmentos do corpo, da alma, da sociedade, da mente.

Para Castoriadis, torna-se prioritário desentranhar forças psíquicas capazes de bater de frente no progresso instrumental, nos cães de guarda do poder e em todos aqueles que, ao lado dos tiranos institucionais, impedem a emergência de uma criação imaginária radical. Por isso, em sua cosmovisão, os profissionais da política são massacrados sem clemência e seus desmandos, corrupções e narcisismos denunciados implacavelmente. Algum paradoxo insolucionável não conseguiu harmonizar conquistas democráticas e maravilhas científicas com a humanização da cultura. Ao contrário disso, ampliaram-se a resignação e a impotência diante da fatalidade da crise, sendo que a reunificação de cidadãos em torno de aspirações coletivas planetárias não se processou como se esperava. Diante da ampliação dos horrores políticos, econômicos e culturais produzida pelo século XX, o sistema planetário sepultou paixões e utopias, substituindo-as por desesperanças e conformidades.

Mesmo assim, é preciso resistir e criar condições de autonomia e liberdade para o pensamento e para a ação. Para dizer a verdade ao poder e às cintilações dele emanadas, não é mais possível pensar apenas como especialista, mas como um "outsider vigilante", que questiona a desumanização cultural. Como reitera Edward Said (1996:33), é preciso experienciar cotidianamente a condição de "intelectual exílico, que não responde à lógica da convenção, mas à da audácia", que transcende os contornos sitiados de sua zona de saber e opta pela condição de amador, preferindo "o risco da incerteza no domínio público - uma conferência, um livro, um artigo - ao espaço fechado e controlado pelos expertos e pelos profissionais" (Said, 1996:43).

$\mathrm{O}$ amadorismo a que se refere Said exige intelectuais polivalentes, universalistas e éticos, que enfrentem com vigor e determinação as contradições do cenário planetário contemporâneo. Para isso, ciência e técnica devem ser entendidas num amplo circuito de ambivalências, mesmo que as maiores descobertas da ciência, como a gravitação universal, a estrutura do átomo, a relatividade, o big-bang, a mecânica quântica e a decifração do genoma, representem momentos irreversíveis que a história humana produziu sobre ela mesma. Por isso, queiramos ou não, estamos vinculados a elas, à infra-estrutura tácita de conceitos e idéias que produziram e às ressonâncias reais e imaginárias que operaram. Mas é sempre bom relembrar que toda essa herança cultural "é para as massas e não apenas para intelectuais de torre de marfim" (Brody e Brody, 1999:25).

Revoluções científicas foi o nome dado a esse conjunto de alterações prodigiosas, produto de mentes inquietas, dominadas pela pulsão da descoberta. Se seu resultado foi mais visível na ampliação da parafernália instrumental e mais oculto na planilha dos conceitos, o fato é que mudaram o estilo do entendimento do mundo, introduziram certezas e semearam incertezas por todo lado. Com o humor de sempre, Freeman Dyson (1998:45) referiu-se a dois estilos contrastantes que cercam a fabricação científica: "a organização e a disciplina rígidas representadas por Napoleão, o caos e liberdade criativos representados por Tolstoi. No mundo dos computadores, Napoleão é o pesado mainframe da IBM: Tolstoi é o humilde Macintosh. A revolução da informática representou uma saída das ambições napoleônicas de Von Neumann em direção à anarquia tolstoiana da Internet". Mesmo que Dyson credite à genética e à neurofisiologia o pódio científico do século XXI, napoleônicos e tolstoianos terão que se unir para derrubar as fronteiras e entender a vida de modo menos linear e mais interdependente, de modo a superar os efeitos que tecnologias civis e militares vêm provocando no crescimento das desigualdades. "O mal pode ser visto em muitas partes do mundo, especialmente nas grandes cidades das Américas do Norte e do Sul" (Dyson, 1998:80).

A tecnologia, enquanto modo de produção cercado por dispositivos instrumentais e de controle postos em ação por predadores inventivos obstinados, criou uma forma inquisitorial que saqueou os tesouros do mundo natural, atirando-os nos compartimentos do poder. Essa cultura fáustica, decadente e trágica, foi responsável pela "montagem de um mundo em miniatura, criado por nós, que se moveria, tal como o Universo, graças à sua energia própria e obedecendo apenas à mão do homem" (Spengler, 1993:102). O questionamento feito por Oswald Spengler, em 1931, sobre essa megamáquina, que exibia uma potência de domínio sem precedentes e atraía a fina flor de indivíduos mais dotados cognitivamente, resumia-se em saber quanto tempo seria ainda necessário para que sua devoração e corrosão se concretizassem.

A irreversibilidade do tempo incumbiu-se de mostrar que a racionalidade e a racionalização padronizaram as relações humanas com velocidade máxima, como se as 
palavras e as coisas dessem as costas para a segunda lei da termodinâmica. Desse modo, individualidade e propriedade passaram a ser entendidas como sinônimas, e isso porque a diminuição do quantum de energia per capita despendido nos processos de trabalho não permitiu a ampliação da criatividade, da liberdade e da autonomia. Como acuradamente percebeu Herbert Marcuse (1999:103), "tal Utopia não seria um estado de felicidade perene. A individualidade natural do homem é também a fonte de sua aflição natural”.

Se o homem traz consigo a marca da felicidade e da aflição, do contingente e do necessário, do prazer e da dor, da dominação e da dependência, constata-se que essa dialética de ambivalências não permitiu a supressão do 'cativeiro da humanidade', mesmo diante dos horrores cotidianos que o planeta vem presenciando. É interessante constatar que, tanto Marcuse quanto Spengler, mesmo situados em campos epistêmicos distintos, produziram essas reflexões entre 1931 e 1941, como que prefigurando, cada um a seu modo, as conseqüências deletérias que o nazifacismo e o nacional-socialismo do terceiro Reich provocariam na alma da civilização planetária. Generalizou-se o mal-estar, embora nesse final milenar corações e mentes "eugênicas" se incumbam de direcionar o futuro da Terra para onde bem pretenderem. O homo-sapiens 2000 se aparenta a um ventríloquo acometido pela experiência da repetição e vacinado contra a experiência da criatividade. É possível que venha a ser geneticamente correto e esterelizado, embora eticamente incorreto, discriminador e relativista.

Reinventou-se a natureza, computou-se o DNA, processou-se a informação em níveis surpreendentes, mas as concepções mecanicistas não foram superadas, malgrado as estruturas dissipativas, os fluxos de dispersão e as tendências reorganizatórias que cercam a impermanência de todos os sistemas vivos. "Com as novas tecnologias, os seres humanos assumem o papel de artistas criativos (...) mas esse novo tipo de arte (...) é uma arte da imitação, cheia de técnicas de cálculo racional, produção em massa e personalização" (Rifkin, 1999:234). Caso a revolução biotecnológica seja mesmo capaz de produzir uma reviravolta no sentido da existência, como acredita Jeremy Rifkin, aprimorando os nexos da vida democrática em escala ampliada, os riscos de uma entropia e de uma desordem generalizadas poderão vir a ser minimizados, desde que o mito do progresso e o antropocentrismo dele decorrente seja colocado em seu devido lugar.

Não se trata mais de restaurar a carcomida querela entre antigos e modernos, ou entre apocalípticos e integra- dos, mas de propor uma política de civilização (Morin e Naïr, 1997) que redefina a vida em comum, entenda o sapiens como meio, fim, objeto e sujeito da política e propicie boas notícias para Gaia. Uma desaceleração nos níveis tecnológicos, acoplada a uma planilha de precauções ético-políticas, não seria impensável para uma renovação de valores experimentais universalistas, que investissem na conservação, na frugalidade, na preservação e se recusassem a reconhecer em Gaia um laboratório de experimentações mefistofélicas de cunho produtivista e inumano.

Uma mudança de escala nesse laboratório sem supervisores nomeados, fundada numa ética valorizadora da convivência entre os seis bilhões de humanos que hoje habitam o planeta, e que amanhã, por volta de 2025 , somarão entre 7,3 e 10,7 bilhões, segundo os últimos dados divulgados pela $\mathrm{ONU}$, poderia vir a restaurar o sentimento da totalidade e da harmonia, assim como a unidade entre mente e matéria, entre ciência e vida tão desprezada ultimamente. Foi esse o tom utilizado por Tseard Zoethout (1999:38) que, ao considerar Spinoza um filósofo da totalidade, afirmou que "uma pessoa tem de olhar o mundo a partir do "ponto da eternidade"". Essa maneira de olhar é verdadeiramente uma arte de conhecimento que requer, acima de tudo, intuição intelectual. Somente assim será possível voltar a reconhecer que a totalidade nunca será capturada pela soma das partes, porque implica sempre a interconexão contraditória e indeterminada de todos os eventos, sejam eles coisas ou idéias, fatos ou representações, amores ou desamores.

Esse sentimento de totalidade requer uma revolução noológica que se defronte contra qualquer forma de colonização. Se esse processo histórico soube invadir as alteridades a partir de 1492, submetendo-as às imposições do dominador, a segunda chegada de Colombo é agora representada pela biopirataria de culturas, plantas, animais. Com a determinação que lhe é peculiar, Vandana Shiva (1997) exemplificou essa colonização interior, referindose ao patenteamento de células e genes realizado pelos próprios homens de ciência. Entre os patenteamentos celulares e os territoriais, é estabelecida apenas uma diferença de natureza. Se os últimos classificavam as culturas não ocidentais como inferiores, pré-lógicas e, portanto, passíveis de apropriação indébita, os primeiros classificam os iguais como privados de vida e direitos, porque sofredores e desesperançados. "Terras e florestas, rios e oceanos, a atmosfera como um todo foram colonizados, erodidos, poluídos. O capital agora tem que se lançar para novas colônias, para invadi-las e explorá-las, a fim de 
garantir sua acumulação futura. Essas novas colônias são os espaços interiores dos corpos das mulheres [e também dos homens], plantas e animais" (Shiva, 1997:13).

Esse deslocamento estratégico da colonização passou a exigir que a ética da vida ocupe cientistas e técnicos de modo inabalável e definitivo. Hans Jonas (1990) que, desde 1979, dedicou-se aos contornos cognitivos do Princípio Responsabilidade, foi mais do que enfático, ao advertir que a civilização técnica carrega consigo uma responsabilidade metafísica, pelo menos "desde que o homem tornou-se perigoso não apenas para ele mesmo, mas para toda a biosfera" (Jonas, 1990:261). A restauração da simbiose homem/natureza é o primeiro passo a ser dado diante da arquitetura do mal perpetrada por intelectos teórico-práticos. A nova obrigação de sujeitos éticos nasce dessa agonia planetária considerada descartável por muitos. Essa ameaça exige, antes de mais nada, "uma ética da conservação (...) do impedimento e não uma ética do progresso e do aperfeiçoamento" (Jonas, 1990:266).

Para Jonas, qualquer ampliação do potencial do Fundus técnico de uma sociedade traz consigo um fardo ético que implica sempre avaliar que o fazer, o saber e o poder nunca constituem apenas um para-si, mas um para-os-outros. "Sacamos hipotecas sobre a vida futura por proveitos e necessidades presentes e de curto prazo e, no que concerne a isso, por necessidades na maioria das vezes autogeradas" (Jonas, 1999:411). Se o preço a pagar pela hipoteca é alto demais para ser resgatado pelas gerações futuras, nossas decisões prático-mundanas trariam para o proscênio ético uma necessária solidariedade inter-humana e isso porque "as conclamações à responsabilidade crescem proporcionalmente aos feitos do poder" (Jonas, 1999:412).

Foi preciso que o planeta se apavorasse com a destruição da biosfera para que riscos técnicos começassem a ser avaliados e criticados por organizações não-governamentais, como a Greenpeace e a Anistia Internacional, dentre outras, que lutam, com a força persuasiva que possuem, contra a desmesura que tomou conta dos donos do poder, esses prometeus modernos para quem as ampliações da técnica são sempre entendidas como irreversíveis. Sabe-se que a irreversibilidade sempre foi um problema para um antropocentrismo decadente, sempre ignorante das lições de vida oferecidas pela dinâmica da natureza. Maravilhados porque desceram das árvores, perderam o rabo, copulam de frente e, mais do que tudo, porque falam, os homo-sapiens se perderam no horizonte crepuscular de uma existência prosaica demais. Demasiadamente humanos, precisam reencontrar-se com a natureza, diluírem-se nela, para que seja possível exercitar a parcimônia diante de apetites vorazes e incontrolados.

Torna-se crucial que assumamos com Jonas a necessidade da temperança antes que seja tarde demais. "Nós podemos até chegar a reduzir a extensão da voragem e voltar a viver com menos, antes que um esgotamento catastrófico ou a poluição do planeta nos constranjam a algo pior que a temperança" (Jonas, 1999:415). Esse algo pior já pode ser constatado em diagnósticos que detectam e, de certa forma, naturalizam a destruição planetária. A Nasa, por exemplo, já admite que gerações futuras possam concentrar-se em "células de sobrevivência", nas quais chips e tamagochis substituirão plantas e animais e um banco espermático acabe de vez com as ambigüidades da repressão sexual. Nessas cidades futuras, talvez só reste aos homens supor que a vida exista em outros planetas e, a partir daí, produzir uma terceira colonização, dessa vez extraterrestre, que se exerceria sobre os sólos áridos de Marte, ou os mares obscuros de Vênus (Santos, 2000:30). $\mathrm{O}$ próprio diretor da agência espacial americana declarou que o objetivo das missões, como a Mars Global Surveyor e a Mars Express, reside na ampliação da fronteira humana (Ball, 2000). Se as suspeitas da existência vierem a se concretizar como insistem os tecnocientistas, a voracidade da exocolonização redefinirá o conceito de vida, como, aliás, já vem sendo ensaiado em encontros recentes que rediscutem as relações entre ciência, tecnologia e sociedade. "A vida é um mecanismo capaz de auto-replicar-se e que evolui de forma darwiniana" (Ball, 2000:20).

Considerações dessa natureza costumam ser ainda entendidas como ficções científicas e, por isso, rotuladas como acrimônicas e anódinas, constituindo-se em prefigurações e projeções de um futuro inglório que ninguém, em sã consciência, deseja. Todo esse estranhamento diante do mundo vem provocando irritações visíveis em pensadores como Peter Sloterdijk (1998), quando referiu-se à perda do olfato dos teóricos diante das tendências globais do processo civilizatório ocidental. Drogados pela ansiedade do sucesso e intoxicados pela cultura da distração, eles não conseguem mais estabelecer a interdependência entre vida, mundo e realidade. A "scienza nuova" da cidadania do mundo funda-se eticamente na formação de "coalizões de atenção", que lutem por uma qualidade evolutiva ampliada que perceba o planeta como "base única para todas as hordas, povos, nações e círculos culturais" (Sloterdijk, 1998:364).

$\mathrm{Se}$, para isso, for preciso reconhecer explicitamente o fracasso do ser humano, que isso seja feito de uma vez. "O 
ser humano poderia até mesmo ser definido como a criatura que fracassou em seu ser-animal (...) e em seu permanecer-animal (Sloterdijk, 2000:34). Acusado de professar um determinismo genético e totalitário, por problematizar algumas das conseqüências advindas da evolução biotécnica, as novas regras do parque humano terão que polemizar sobre o velho humanismo antropocêntrico e reler a longa história das relações entre animalidade e humanidade, assim como experienciar a incerteza das fronteiras entre as histórias da natureza e da cultura. O que está colocado em xeque é o caráter derrisório da noção de humanidade. A humanitas não implica apenas amizade e entendimento, mas também reconhecimento do poder de homens sobre homens. "A história real da clareira (...) consiste, portanto, de duas narrativas maiores que convergem em um perspectiva comum, a saber, a explicação de como o animal sapiens se tornou o homem sapiens" (Sloterdijk, 2000:33) e, simultaneamente, demens.

Essa perspectiva comum requer um outro modo de pensar e fazer, uma aceitação da responsabilidade social destinada a impedir que a política do pior floresça. Esse é o papel reservado a intelectuais capazes de identificar, no largo espectro das tensões sociais, uma utopia social viável, uma arquitetura, ou seja, um paradigma da coerência construtiva que recombine tensões e integridades, razões e desrazões. Trata-se, em resumo, de agir e participar sempre que possível, mesmo que a perdição seja grande e a tentação do refúgio paranóico maior ainda. A imagem do cientista ambicioso, isolado da natureza e dos afetos, criador de criaturas, deve ser superada, para dar lugar ao cientista amoroso, capaz de fazer dialogar o sensato e o insensato que sempre marcou a aventura humana.

Com isso, talvez seja possível aplacar os monstros da razão e perceber que a vida é bela, apesar das desavenças e domesticações que a historialidade imprimiu ao cientista, compelindo-o a optar entre um racionalismo redutor e um idealismo apaixonado. "Faça-me feliz e eu serei de novo virtuoso" foi o apelo desesperado que o monstro dirigiu a Victor Frankenstein para que o deixasse viver, malgrado os ódios e desprezos que todos lhe dirigiam. $\mathrm{O}$ criador não se deu conta que o monstro, considerado com um fragoroso erro experimental, era o duplo dele mesmo. Deixando-o sucumbir, devorou-se a si próprio e mergulhou definitivamente na infelicidade da hubris. Se a me- táfora criada por Mary Shelley em 1818 (1985) fosse teletransportada para 2000 , poder-se-ia supor que felicidade e virtuosidade são invariantes da alma e que a tecnociência, por mais pretensiosa que seja, não tem o direito de impedir que elas floresçam nas criações humanas, sejam elas reais ou imaginárias.

\section{REFERÊNCIAS BIBLIOGRÁFICAS}

BALL, P. "Sueños poco realistas de la Nasa para Marte". El Pais, 21/09/2000. BRODY, D.E. e BRODY, A.R. As sete maiores descobertas cientificas da história. Trad. Laura Teixeira Motta. São Paulo, Cia. das Letras, 1999.

CASTORIADIS, C. La montée de l'insignifiance. Les carrefours du labyrinthe $I V$. Paris, Seuil, 1996.

DYSON, F. Mundos imaginados. Trad. Claudio W. Abramo. São Paulo, Cia. das Letras, 1998.

JONAS, H. Le principe responsabilité. Une éthique pour la civilisation technologique. Trad. Jean Greisch. Paris, Flammarion, 1990.

"Por que a técnica moderna é um objeto para a ética". Trad. Oswaldo Giaccoia Jr. Natureza Humana, Revista Internacional de Filosofia e Práticas Psicoterápicas. São Paulo, Educ, v.1, n.2, 1999, p.407-422.

LÉVI-STRAUSS, C. La pensée sauvage. Paris, Plon, 1962.

MARCUSE, H. Tecnologia, guerra e fascismo. Trad. Maria Cristina Vidal Borba. São Paulo, Editora Unesp, 1999.

MORIN, E. e NAÏR, S. Une politique de civilisation. Paris, Arléa, 1997.

PASSET, R. "Potentialités pervertis des technologies". Manière de Voir, 38. Le monde diplomatique, mars-avril 1998, p.64-69.

RAMONET, I. Geopolitica do caos. Trad. Guilherme J. de Freitas Teixeira. Petrópolis, Vozes, 1998.

"Pour l'avenir de l'humanité". Manière de voir, 38. Le monde diplomatique. Ravages de la technoscience, mars-avril 1998, p.7.

RIFKIN, J. O século da biotecnologia. A valorização dos genes e a reconstrução do mundo. Trad. Arão Shapiro. São Paulo, Makron Books, 1999.

ROSSI, P. Naufrágios sem espectador. A idéia de progresso. Trad. Álvaro Lorencini. São Paulo, Editora da Unesp, 2000.

SAID, E.W. Des intellectuels et du pouvoir. Paris, Seuil, 1996.

SANTOS, R. "Uma viagem ao futuro assustador previsto pelos cientistas da NASA". Valor, 8, 9 e 10 de dezembro de 2000.

SHELLEY, M. Frankenstein: o moderno Prometeu. Trad. Miécio Araujo Honkis. Porto Alegre, L \& PM, 1985.

SHIVA, V. "The second coming of Columbus". Resurgence, n.182, may-june 1997, p.12-14.

SLOTERDIJK, P. Extrañamiento del mundo. Trad. Eduardo Bera. Valencia, PreTextos, 1998.

Regras para o parque humano. Uma resposta à carta de Heidegger sobre o humanismo. Trad. José Oscar de Almeida Marque. São Paulo, Estação Liberdade, 2000.

SNOW, C.P. As duas culturas e uma segunda leitura. Trad. Geraldo G. de Souza/Renato de A. Rezende. São Paulo, Edusp, 1995.

SPENGLER, O. O homem e a técnica. Trad. João Botelho. Lisboa, Guimarães eds. 1993.

ZOETHOUT, T. “A philosopher of wholeness”. Resurgence, n.196, sep.-oct. 1999, p.37-38. 